\title{
Socio-economic Security in the System of Transition to Sustainable Development of the Mining Region
}

\author{
Natalia Kudrevatykh ${ }^{1, *}$, Ekaterina Slesarenko $^{1}$, and Yigit Yilmaz $^{2}$ \\ ${ }^{1}$ T.F. Gorbachev Kuzbass State Technical University, Department of Finace and Credit, 650000 \\ Kemerovo, 28 Vesennya st., Russian Federation \\ ${ }^{2}$ Kastamonu University Sabahat Mesut Y1lmaz, 37970 Mustafa Dicel Sk., Kastamonu, Turkey
}

\begin{abstract}
The aim of the article is an assessment the socio-economic security of a mining region. The article describes the assessment socioeconomic security of Kemerovo region by the technique that consists of economic and social components. Results of assessment showed a low level of socio-economic security of Kemerovo region. Majority of analyzed parameters in Kemerovo region has low indicators of socioeconomic security. Indicators of assessment socio-economic security of Kemerovo region are at a level below then the average for the Siberian Federal district.
\end{abstract}

\section{Introduction}

The socio-economic security of the region is of great importance for the maintenance of national security and the integrity of the country. The ability to ensure national security means high competitiveness, socio-economic development and a decent quality of life of citizens in today's unstable and constantly changing environment. A developed and competitive economy is the basis for social stability. Therefore, social and economic security issues are interlinked.

A significant amount of paper is devoted to issues of economic security in a whole and its individual elements [1-20].

Numerous types of regional security, such as industrial, socio-economic, financial, environmental, energy, transport, information, food, etc, are distinguished as parts of economic security.

Social and economic security is a core of development of the region in particular, and the country as a whole in constantly changing conditions of economy functioning.

\section{Materials and Methods}

This article presents an assessment of socio-economic security of Kemerovo region according to the technique developed at Omsk scientific center SB RAS [21].

\footnotetext{
* Corresponding author: knv.fk@kuzstu.ru
} 
When developing a system of indicators of region economic security, the postulate about the presence of regional specifics was taken as a basis. Features of each region are explained by the geographical location, the presence of certain natural resources, transport routes, historical specific factors that influenced the development of the territory.

In this approach the problem of the need for inter-regional comparisons is solved. Therefore, only universal and typical for all regions parameters of socio-economic security were included in the assessment technique. All indicators are grouped into economic, social and financial field. In accordance with the purpose and objectives of this study, the first two fields will be considered and used in the analysis.

\section{Results}

Results of assessment showed a low level of socio-economic security of Kemerovo region. Majority of analyzed parameters Kemerovo region has low indicators of socio-economic security. Comparative assessment of the situation in Kemerovo region among regions of Siberian Federal district showed that indicators for assessing the socio-economic security of Kemerovo region are below the average for Siberian Federal district. This situation requires the adoption of countermeasures aimed at improving socio-economic security.

\section{Discussion}

Considering Kemerovo region from the position of socio-economic security we can notice that the region was and still is non-diversified. The basis of the region's security is coal, and this fact makes it dependent on foreign markets. The specifics of the mining region, such as unfavorable environmental situation, the dependence of the labor market on one basic branch of specialization, etc., puts the solution of the problems of increasing its socioeconomic security at the forefront.

The specificity difference between Kemerovo region and other regions of Siberian Federal district is in the high concentration of industry and population. The population density of Kemerovo region is three times higher than in the neighboring regions, besides high proportion of urban population is great $(85.6 \%)$.

Assessing actual values of analyzed indicators, we carried out a comparative characteristic was carried out criteria of socio-economic indicators and their dynamics.

Comparative characteristics of Kemerovo region among SFD regions on the indicators of security in the economics is presented in table 1 .

Table 1. Comparative characteristics of indicators of security in economic field in Kemerovo region and SFD regions.

\begin{tabular}{|c|c|c|c|c|c|c|c|c|c|c|c|c|c|}
\hline \multirow{2}{*}{ № } & \multirow{2}{*}{ Indicator } & \multicolumn{12}{|c|}{ Place among SFD regions } \\
\hline & & 1 & 2 & 3 & 4 & 5 & 6 & 7 & 8 & 9 & 10 & 11 & 12 \\
\hline 1 & GRP per capita & & & & & & & & & & & & \\
\hline 2 & Industrial production per capita & & & & & & & & & & & & \\
\hline 3 & Agricultural production per capita & & & & & & & & & & & & \\
\hline 4 & $\begin{array}{l}\text { Share of manufacturing in the } \\
\text { volume of shipped goods and } \\
\text { services of own production }\end{array}$ & & & & & & & & & & & & \\
\hline 5 & $\begin{array}{l}\text { Share of mechanical engineering } \\
\text { in the volume of shipped goods } \\
\text { and services of own production* }\end{array}$ & & & & & & & & & & & & \\
\hline 6 & Depreciation of fixed assets & & & & & & & & & & & & \\
\hline 7 & Retail turnover per capita & & & & & & & & & & & & \\
\hline 8 & Volume of paid services per & & & & & & & & & & & & \\
\hline
\end{tabular}




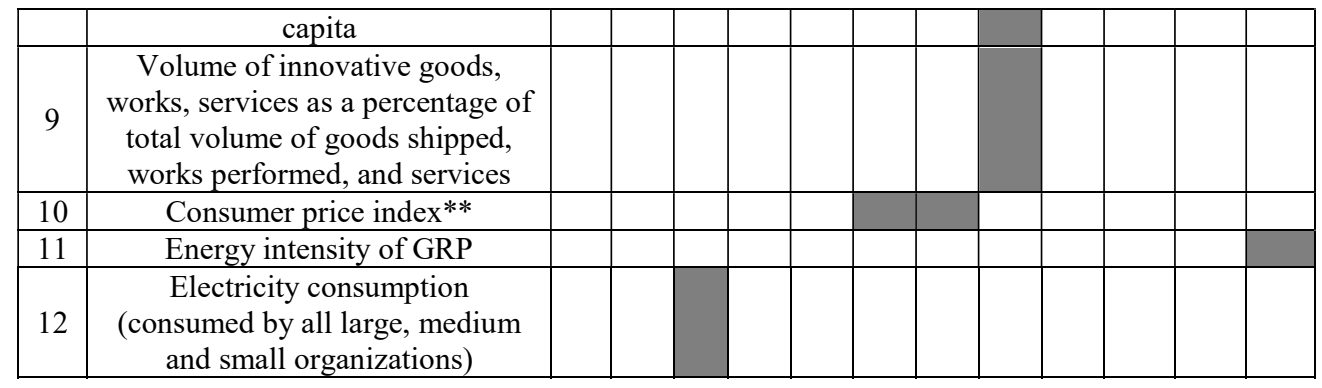

* In public statistical sources for the assessment of socio-economic security of Kemerovo region there are no data on the volume of production of engineering or the share of this indicator in a volume of shipped goods and services of own production in SFD regions. So a comparison of the position of Kemerovo region among Siberian regions is not possible.

** Shares with Omsk region

As it can be seen from the presented data, excepting parameters related to industrial production (volume of production and consumption of electricity), Kemerovo region ranks in the second half of the rating of SFD regions. On average, the region ranks eighth in indicators of economic component of socio-economic security. The most difficult situation is with the energy intensity of GRP production, manufacturing, and low turnover of retail trade per capita.

Comparative characteristics of Kemerovo region among SFD regions on the indicators of safety in the social field is presented in table 2 .

Table 2. Comparative characteristics of indicators of safety in the social field in Kemerovo region and SFD regions.

\begin{tabular}{|c|c|c|c|c|c|c|c|c|c|c|c|c|c|}
\hline \multirow{2}{*}{ № } & \multirow{2}{*}{ Индикатор } & \multicolumn{12}{|c|}{ Place among SFD regions } \\
\hline & & 1 & 2 & 3 & 4 & 5 & 6 & 7 & 8 & 9 & 10 & 11 & 12 \\
\hline 13 & Annual population dynamics & & & & & & & & & & & & \\
\hline 14 & $\begin{array}{l}\text { Natural population growth } \\
\text { rate per } 1,000 \text { population }\end{array}$ & & & & & & & & & & & & \\
\hline 15 & $\begin{array}{l}\text { Migration growth rate per } \\
10,000 \text { population }\end{array}$ & & & & & & & & & & & & \\
\hline 16 & Life expectancy at birth & & & & & & & & & & & & \\
\hline 17 & Unemployment rate & & & & & & & & & & & & \\
\hline 18 & $\begin{array}{l}\text { Real incomes of the } \\
\text { population }\end{array}$ & & & & & & & & & & & & \\
\hline 19 & $\begin{array}{l}\text { Average per capita income } \\
\text { (per month) }\end{array}$ & & & & & & & & & & & & \\
\hline 20 & $\begin{array}{l}\text { Differentiation of incomes } \\
\text { rate }\end{array}$ & & & & & & & & & & & & \\
\hline 21 & $\begin{array}{l}\text { Ratio of per capita monetary } \\
\text { income of the population to } \\
\text { the subsistence minimum }\end{array}$ & & & & & & & & & & & & \\
\hline 22 & $\begin{array}{l}\text { Population with monetary } \\
\text { income below the subsistence } \\
\text { minimum (of the total } \\
\text { population) }\end{array}$ & & & & & & & & & & & & \\
\hline 23 & $\begin{array}{l}\text { Total area of residential } \\
\text { premises per inhabitant } *\end{array}$ & & & & & & & & & & & & \\
\hline 24 & $\begin{array}{l}\text { Number of crimes per } 100 \\
\text { thousand people }\end{array}$ & & & & & & & & & & & & \\
\hline
\end{tabular}

* Shares with Novosibirsk region and Krasnoyarsk territory 
Among the indicators of social security the position of Kemerovo region is slightly better. On average, the region ranks seventh in the SFD.

In accordance with the assessment technique, the level of socio-economic security is further determined. The calculation is presented in table 3 .

Table 3. Assessment of the level of socio-economic security of Kemerovo region.

\begin{tabular}{|c|c|c|c|}
\hline № & Indicator & Marks & Commentary \\
\hline 1 & GRP per capita & 0 & below the threshold \\
\hline 2 & Industrial production per capita & 2 & above the threshold \\
\hline 3 & Agricultural production per capita & 0 & below the threshold \\
\hline 4 & $\begin{array}{l}\text { Share of manufacturing in the volume of shipped } \\
\text { goods and services of own production }\end{array}$ & 0 & below the threshold \\
\hline 5 & $\begin{array}{l}\text { Share of mechanical engineering in the volume of } \\
\text { shipped goods and services of own production* }\end{array}$ & 0 & below the threshold \\
\hline 6 & Depreciation of fixed assets & 0 & below the threshold \\
\hline 7 & Retail turnover per capita & 0 & below the threshold \\
\hline 8 & Volume of paid services per capita & 0 & below the threshold \\
\hline 9 & $\begin{array}{l}\text { Volume of innovative goods, works, services as a } \\
\text { percentage of total volume of goods shipped, } \\
\text { works performed, and services }\end{array}$ & 0 & below the threshold \\
\hline 10 & Consumer price index** & 1 & equal to the threshold \\
\hline 11 & Energy intensity of GRP & 0 & below the threshold \\
\hline 12 & $\begin{array}{l}\text { Electricity consumption (consumed by all large, } \\
\text { medium and small organizations) }\end{array}$ & 2 & above the threshold \\
\hline 13 & Annual population dynamics & 1 & equal to the threshold \\
\hline 14 & $\begin{array}{l}\text { Natural population growth rate per } 1,000 \\
\text { population }\end{array}$ & 0 & below the threshold \\
\hline 15 & Migration growth rate per 10,000 population & 0 & below the threshold \\
\hline 16 & Life expectancy at birth & 0 & below the threshold \\
\hline 17 & Unemployment rate & 0 & below the threshold \\
\hline 18 & Real incomes of the population & 1 & equal to the threshold \\
\hline 19 & Average per capita income (per month) & 0 & below the threshold \\
\hline 20 & Differentiation of incomes rate & 0 & below the threshold \\
\hline 21 & $\begin{array}{l}\text { Ratio of per capita monetary income of the } \\
\text { population to the subsistence minimum }\end{array}$ & 0 & below the threshold \\
\hline 22 & $\begin{array}{l}\text { Population with monetary income below the } \\
\text { subsistence minimum (of the total population) }\end{array}$ & 0 & below the threshold \\
\hline 23 & Total area of residential premises per inhabitant * & 1 & equal to the threshold \\
\hline \multirow[t]{2}{*}{24} & Number of crimes per 100 thousand people & 0 & below the threshold \\
\hline & TOTAL & 8 & Critical level \\
\hline
\end{tabular}

The assessment showed a critical level of socio-economic security in accordance with the scale presented in table 4 .

Table 4. Scale of assessment of economic security of the region [21].

\begin{tabular}{|c|c|c|c|}
\hline $\begin{array}{c}\text { Security } \\
\text { level }\end{array}$ & Interval & $\begin{array}{c}\text { The security } \\
\text { situation in the } \\
\text { region }\end{array}$ & Procedure \\
\hline Low & $0-9$ & Critical & $\begin{array}{c}\text { Crisis management, development of regional } \\
\text { development strategy, radical restructuring of } \\
\text { management system }\end{array}$ \\
\hline
\end{tabular}




\begin{tabular}{|c|c|c|c|}
\hline & $10-18$ & Crisis & $\begin{array}{c}\text { Localization of the crisis, minimization of } \\
\text { negative consequences, restoration of } \\
\text { economic security of the region }\end{array}$ \\
\hline Medium & $19-27$ & Acceptable & Measures to prevent and counteract the crisis \\
\hline \multirow{2}{*}{ High } & $28-37$ & Normal & $\begin{array}{c}\text { Support at the current level, measures to } \\
\text { prevent crisis }\end{array}$ \\
\cline { 2 - 4 } & $38-48$ & Stable & Support at the current level \\
\hline
\end{tabular}

Having a high level of economic security in industrial production volume per capita and a high level of energy consumption (it also indicates the development of industry), Kemerovo region lags behind the volume of GRP per capita. Production of agricultural products, manufacturing and engineering ones is insufficiently developed in the region. Industrial production in Kemerovo region is extensive and is based on the potential formed in the last century. This fact is evidenced by the high depreciation of fixed assets, high energy consumption of GRP. This state of industry does not correspond to the current and future development trends. The focus on coal mining and heavy industries is not conducive to dynamic modern development. The low level of innovative goods, works and services as part of the total volume of shipped goods, works and services shows that there are no effective mechanisms to stimulate innovative development in Kemerovo region.

Low level of economic security indicators on retail trade turnover per capita and paid services also reflect the insufficient level of development of consumer goods and services production.

As a result, the economic security of Kemerovo is estimated lower than in most SFD regions.

Despite the fact that in the social fields in some respects Kemerovo region has positions that characterize the average level of social security and a high place among SFD regions, the negative level of natural and migration growth characterizes Kemerovo region as an unfavorable region for people and the supply of their labor force.

Social security in indicators of unemployment, income and poverty is low. Level of crime in Kemerovo region is much ahead of average indicators of Russia and almost all neighboring regions. It also does not have a positive impact on the attractiveness of Kemerovo region for people living.

The critical level of socio-economic security involves the introduction of anti-crisis management measures, the implementation of the regional development strategy aimed at improving socio-economic security, a radical restructuring of the management system.

\section{Conclusion}

The assessment showed a low level of socio-economic security of Kemerovo region. For most of analyzed parameters Kemerovo region has low indicators of socio-economic security. Indicators of assessment of socio-economic security of Kemerovo region are at a level below the average ones for SFD. On average, according to economic indicators, Kemerovo region ranks 8th among 12 regions, on social it has 7 th place.

The critical nature of the socio-economic security of the region necessitates strict measures to ensure a high level of socio-economic security. The ongoing restructuring of the management system of Kemerovo region is just one of steps of crisis management in the region. A new regional development strategy has been developed and is being implemented. It is aimed at the systematic and strategic nature of the socio-economic security of Kemerovo region. 


\section{References}

1. R. Baodong, International Journal of Financial Research, 2:2, 20 (2011)

2. D. A. Baldwin, Review of International Studies, 23:1, 5 (1997)

3. B. Higgins, D. D. Savoie, Regional development: Theories and their application (Transaction Publishers, New Brunswick, 1995)

4. M. Bussiure, J. Imbs, R. Kollmann, R. Ranciure, American Economic Journal: Macroeconomics, 5, 75 (2013)

5. R. Capone, H. El Bilali, P. Debs, Journal of Food Security, 2:1, 13 (2014)

6. R. Capone, Y. El Bilali, P. Debs, Journal of Food Security, 2:1, 1 (2014)

7. L. Dadao, F. Jie, Regional Development Research in China: A Roadmap to 2050 (Beijing, Science Press, 2011)

8. F. Echterling, B. Eierle, S. Ketterer, International Review of Financial Analysis, 42, 235 (2015)

9. S. M. Glover, D. F. Prawitt, W. F. V. Messier, Auditing \& Assurance Services: A systematic approach (McGraw-Hill, New York, 2014)

10. J. K. Galbraith, Economics and the Public Purpose (Houghton Mifflin Company, Boston, 1973)

11. D. E. Karen, Journal of Economic Perspectives, 23, 49 (2009)

12. M. M. Kevin, R. H. Topel, American Economic Review, 103, 508 (2013)

13. L. A. Kormishkina, E. D. Kormishkin, N. N. Semenova, D. A. Koloskov, Mediterranean Journal of Social Sciences, 6:4, 163 (2015)

14. N. Kudrevatykh, O. Sheveleva, Coal in the 21st Century: Mining, Processing and Safety, 120 (2016)

15. K. M. Murphy, R. H. Topel, American Economic Review, 103:3, 508 (2013)

16. E. L. Perroux, Presses Universitaires Grenoble, 14:1, 63 (1963)

17. P. Pottier, Revue Economique, 1, 63 (1963)

18. Sustainable Economic Development. Resources, Environment and Institutions (Academic Press, Massachusetts, 2015).

19. Yu. A. Fridman. G. N. Rechko, A. G. Pimonov, Regional Research of Russia, 2:3, $206(2012)$

20. W. Z. Hirsch, The economics of state and local government (HILL Book Company, London, 1970)

21. A. A. Korableva, Bulletin of the Siberian institute of business and information technologies, 3, 36 (2017) 